\title{
Deregulated expression of the per 2 gene in human colorectal carcinoma
}

\author{
MICHAL ZEMAN $^{1}$, MARIÁN VICIAN ${ }^{2}$, JANA MONOSÍKOVÁ ${ }^{1}$, RICHARD REIS $^{2}$ and IVETA HERICHOVÁ ${ }^{1}$ \\ ${ }^{1}$ Department of Animal Physiology and Ethology, Faculty of Natural Sciences; ${ }^{2}$ First Surgery Department, \\ Medical Faculty and Hospital, Comenius University Bratislava, 84215 Bratislava, Slovak Republic
}

Received April 3, 2008; Accepted May 23, 2008

\begin{abstract}
The circadian system is involved in the control of cell proliferation and apoptosis. The aim of this study was to analyze expression of the human per 2 gene in patients who underwent surgery for colorectal carcinoma. The study included 25 patients of both genders. Patients were exposed to light from 6:00 a.m. until 9:00 p.m. according to standard hospital practice. Tissue samples were taken from the tumor as well as from the proximal and distal areas of the resected colon at the time of surgery. Surgery was performed during the morning hours. Expression of per 2 mRNA was measured by real-time PCR. There was a significant negative correlation between per 2 gene expression and tumor staging. Expression of per 2 mRNA did not correlate with whether the tumor was localized in the colon or rectum. In comparison with ectomized tissue without malignancy from patients with colorectal carcinoma, our data demonstrate per 2 mRNA deregulation in tumor tissue, and suggest a way in which the circadian system can influence tumorigenesis.
\end{abstract}

\section{Introduction}

Alteration of the natural 24-h light/dark cycle and subsequent disruption of the circadian rhythms is involved in increased susceptibility to different kinds of cancer in humans. Epidemiological studies have demonstrated an increased risk of colorectal (1) and breast (2-4) cancer in women exposed to shift work over prolonged periods of time. It is expected that disturbed biological rhythms, resulting from prolonged shift work and/or light exposure at night, represent important risk factors for cancer development.

Biological rhythms with a period close to $24 \mathrm{~h}$ (circadian rhythms) are efficiently orchestrated by the circadian timing system, consisting of the central and peripheral oscillators. The central oscillator is localized in the suprachiasmatic nucleus

Correspondence to: Dr Iveta Herichová, Department of Animal Physiology and Ethology, Comenius University Bratislava, Mlynská dolina B-2, 84215 Bratislava, Slovak Republic

E-mail: herichova@fns.uniba.sk

Key words: circadian, K-ras, mrpl19, clock genes, cancer
$(\mathrm{SCN})$ of the hypothalamus, while peripheral oscillators are present in most of the cells of the body (5). The central oscillator governs the peripheral oscillators; however, in some circumstances the peripheral oscillators can become disconnected from the SCN and run independently (6-8). The generation of biological rhythms is based on the molecular oscillations of clock genes, which create interacting positive and negative transcriptional feedback loops. Several clock genes have been identified in mammals. Of these, the per genes (per 1, per 2 , per3) play a key role as negative regulators (9). PER proteins create heterodimers with the protein products of cry genes and, in this form, are translocated to the nucleus. In the nucleus, PER:CRY interacts with another heterodimer created by transcriptional factors, BMAL:CLOCK. BMAL:CLOCK (or its functional homologue) stimulates per and cry gene expression via the E-box in their regulatory regions, while the PER:CRY complex inhibits this process. When the transcription and subsequent translation of per and cry genes is efficiently down-regulated, the inhibition of BMAL:CLOCK is lifted due to the absence of the PER:CRY heterodimer. The transcription of the per and cry genes is then restarted. This chain of events takes place over a period close to $24 \mathrm{~h}$, and determines circadian oscillator function (5).

Interconnectivity between the clock function and the cell cycle is presumably mediated by clock controlled genes and transcriptional factors, since disruption of the clock function has a significant impact on cell division (10-12). Hyperplasia can either result from a greater proliferative rate or from a lower rate of apoptosis. PER proteins seem to be involved in both processes. Mice deficient in the per 2 gene show higher sensitivity to ionizing radiation and a higher incidence of spontaneous cancer in comparison with wild-type mice (10). The E-box mediated mechanism participates in the activation of the Wee1 kinase, which negatively controls cyclin-dependent kinase 1 activity and the G2-M transition of cell division (11). Another known functional connection between the circadian clock and cell proliferation involves the proto-oncogene $c$-myc, which plays a role in the regulation of several cell cycle transitions. Expression of the $c$-myc gene was found upregulated in the liver of per 2 gene deficient mice and, via the E-box mediated mechanism, basic clock components were able to influence $c$-myc expression (10).

Deregulated per gene expression has been observed in mice following tumor transplantation (13). Exposure of the animals to an irregular light/dark regime resulted in further 
disturbance of clock gene expression $(14,15)$. Up-regulation of PER protein leads to the suppression of tumor growth (16-20), thus implicating PER in cell cycle regulation.

Expression of clock genes has previously been demonstrated in human healthy and cancerous tissue of the gastrointestinal tract $(21,22)$. We hypothesize that decreased expression of the per 2 gene may contribute to colorectal cancer development. The aim of this study was therefore to determine the expression of the per 2 gene in colonic tumors and in the distal and proximal parts of resected tissue that exhibited no signs of malignancy. We correlated per 2 gene expression with tumor localization and stage and with mutations in the human proto-oncogene $K$-ras, which is frequently mutated in colorectal carcinoma and contributes to the early developmental stages of this cancer.

\section{Materials and methods}

The study comprised 25 patients of both genders (age 71.88土 1.47 , range 59-85 years) with colonic cancer. Patients were exposed to light from 6:00 a.m. to 9:00 p.m. according to standard hospital practice (First Surgery Department, Medical Faculty and Hospital, Comenius University, Bratislava). The protocol was explained to each patient and informed consent was obtained.

Histopathological examinations were performed by a hospital pathologist. Tissue samples were taken during surgery, collected from the tumor as well as from the proximal ( $\geq 10 \mathrm{~cm}$ from the tumor) and distal ( $\geq 2 \mathrm{~cm}$ from the tumor) areas of the resected gut. Surgery was carried out between 10.00 a.m. and 1.00 p.m. The removed samples were collected in liquid nitrogen and stored at $-80^{\circ} \mathrm{C}$ until use for RNA extraction.

Gene expression. Total-RNA was isolated from the tissue using Tri-reagent (MRC, USA) according to the manufacturer's instructions. Synthesis of cDNA was performed with ImProm-II Reverse Transcription System (Promega, USA) according to the manufacturer's instructions.

Quantification of cDNA was performed by real-time PCR with the QuantiTect SYBR Green PCR Kit (Qiagen, Germany) and the ABI PRISM ${ }^{\circledR 7900 H T ~ S e q u e n c e ~ D e t e c t i o n ~ S y s t e m ~}$ (Applied Biosystems, USA). The primer pairs used for the amplification of each product were: per2 (GenBank accession no. NM022817.1) sense 5'-AATGCCGATATGTTTGC GGT-3', antisense 5'-GCATCGCTGAAGGCATCTCT-3'; mrpl19 (GenBank accession no. NM014763.3) sense 5'-GGG ATTTGCATTCAGAGATCAG-3', antisense 5'-GGAAGG GCATCTCGTAAG-3' (23). Real-time PCR conditions were: activation of hot start polymerase at $95^{\circ} \mathrm{C}$ for $15 \mathrm{~min}$ followed by 50 cycles at $94^{\circ} \mathrm{C}$ for $15 \mathrm{sec}, 49^{\circ} \mathrm{C}$ for $30 \mathrm{sec}$ and $72^{\circ} \mathrm{C}$ for $30 \mathrm{sec}$. Amounts of reverse transcription product were 1.6 and $0.8 \mu 1$ for per 2 and mrpl19, respectively. The specificity and identity of the PCR products were validated by melting curve analysis and gel electrophoresis. The fluorescence dye ROX served as an internal reference for normalization of the SYBR Green I fluorescent signal. Samples to be compared were assayed using the same mastermix on one plate.

Detection of $K$-ras mutation in codons 12 and 13 . Frozen tissue (65-75 mg) was dissected using a sterile scalpel into 1-2 mm sections. Samples were incubated overnight at room temperature in $0.5 \mathrm{ml}$ DNAzol (MRC) with $50 \mu \mathrm{g}$ proteinase $\mathrm{K}$ (Fermentas, Canada). The next day, DNA was isolated with DNAzol according to the manufacturer's instructions. Samples were dissolved in $0.8 \mathrm{mM} \mathrm{NaOH}$. DNA was amplified by mutagenic PCR assay (24). A mismatched upstream primer for codon 12 and downstream primer for codon 13 were used to introduce the $M v a \mathrm{I}$ and $B s u \mathrm{RI}$ restriction sites, respectively. The primer pairs used for amplification were: K-ras codon 12 sense 5'-ACTGAATATAAACTTGTGGTAGTTGGACCT-3', antisense 5'-CTGTATCAAAGAATGGTCCTGCACCA GTA-3'; K-ras codon 13 sense 5'-GTACTGGTGGAGTAT TTGATAGTGTATTAA-3', antisense 5'-GTATCGTCAAG GCACTCTTGCCTAGG-3' (the underlined bases represent mismatches).

The PCR reaction $(50 \mu 1)$ contained: $200-350 \mathrm{ng}$ DNA, $1 \mathrm{X}$ reaction buffer with $\mathrm{KCl}, 0.2 \mathrm{mM}$ each dNTP, $1.5 \mathrm{mM}$ $\mathrm{MgCl}_{2}, 0.5 \mu \mathrm{M}$ specific primers and $1 \mathrm{U}$ Taq DNA polymerase (Fermentas). PCR conditions for K-ras codon 12 were: initial denaturation at $95^{\circ} \mathrm{C}$ for $5 \mathrm{~min}$ followed by 35 cycles at $94^{\circ} \mathrm{C}$ for $40 \mathrm{sec}, 60^{\circ} \mathrm{C}$ for $30 \mathrm{sec}$ and $72^{\circ} \mathrm{C}$ for $30 \mathrm{sec}$. For K-ras codon 13 , the annelation step was performed at $50^{\circ} \mathrm{C}$ and the final extension step lasted $3 \mathrm{~min}$. The size of the PCR products was validated by electrophoresis on $2 \%(\mathrm{w} / \mathrm{v})$ agarose gel.

Amplified samples $(10 \mu \mathrm{l})$ were digested with $5 \mathrm{U}$ MvaI (Fermentas) for K-ras codon 12 and 5 U BsuRI (Fermentas) for $\mathrm{K}$-ras codon 13 at $37^{\circ} \mathrm{C}$ overnight. Restriction fragments were separated by electrophoresis performed in $3.5 \%(\mathrm{w} / \mathrm{v})$ MetaPhor agarose (Cambrex, USA) in Trisborate-EDTA buffer. The product was visualized by UV transillumination following ethidium bromide staining.

Statistical evaluation. Differences in per 2 gene expression were compared using the unpaired Student's t-test or ANOVA, depending on the number of groups to be compared. The Spearman rank correlation coefficient test was used to reveal the relationship between per 2 gene expression and tumor staging.

\section{Results}

Patients were divided into three groups according to cancer staging (Table I). The first group comprised patients with primary tumors confined to the gut with no lymph node or distant metastases $\left(\mathrm{T}_{1-3} \mathrm{~N}_{0} \mathrm{M}_{0} ; \mathrm{n}=16\right)$; the second group comprised patients with lymph node but without distant metastases $\left(\mathrm{T}_{2-3} \mathrm{~N}_{1} \mathrm{M}_{0} ; \mathrm{n}=5\right)$, and the third group comprised patients with distant metastases $\left(\mathrm{T}_{3-4} \mathrm{~N}_{1-2} \mathrm{M}_{1} ; \mathrm{n}=4\right)$.

Relative values of per 2 gene expression in tumor tissue (Fig. 1) show a significant negative correlation between per2 gene expression and tumor staging $(\mathrm{P}<0.05 ; \mathrm{R}=0.44)$. Tumor localization in patients is described in Table I. No significant difference between per 2 gene expression in the colon and rectum was found (Fig. 2).

To analyze per 2 mRNA expression in cancer and adjacent tissues in relation to tumor staging, patients were divided into three groups (Fig. 3, Table I). The relative expression of the per2 gene was evaluated as the ratio of expression in cancer tissue to expression in the adjacent part of the colon. In patients with no distant metastases, the ratio of cancer/adjacent tissue 
Table I. Tumor distribution.

\begin{tabular}{|c|c|c|c|c|c|c|}
\hline & No. & Women & Men & Ascendent colon & Descendent colon & Rectum \\
\hline $\mathrm{T}_{1-3} \mathrm{~N}_{0} \mathrm{M}_{0}$ & 16 & 6 & 10 & 9 & 0 & 7 \\
\hline $\mathrm{T}_{2-3} \mathrm{~N}_{1} \mathrm{M}_{0}$ & 5 & 2 & 3 & 3 & 1 & 1 \\
\hline $\mathrm{T}_{3-4} \mathrm{~N}_{1-2} \mathrm{M}_{1}$ & 4 & 3 & 1 & 2 & 2 & 0 \\
\hline Total & 25 & 11 & 14 & 14 & 3 & 8 \\
\hline
\end{tabular}

$\mathrm{T}_{1-3} \mathrm{~N}_{0} \mathrm{M}_{0}$, patients with primary tumors confined to gut, with no lymph node or distant metastases; $\mathrm{T}_{2-3} \mathrm{~N}_{1} \mathrm{M}_{0}$, patients with lymph node metastases but with no distant metastases; $\mathrm{T}_{3-4} \mathrm{~N}_{1-2} \mathrm{M}_{1}$, patients with distant metastases.

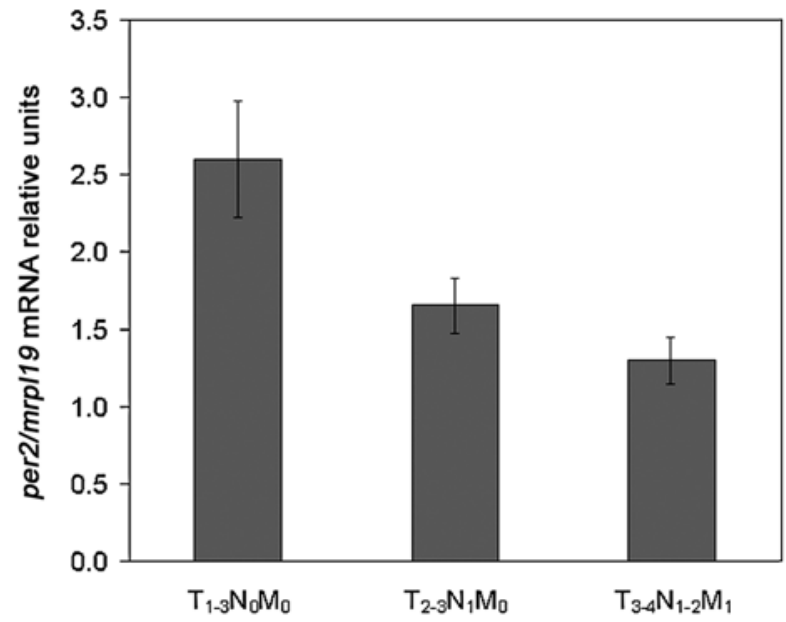

Figure 1. Correlation between per 2 mRNA expression in cancer tissue and tumor staging. $\mathrm{T}_{1-3} \mathrm{~N}_{0} \mathrm{M}_{0}$, patients with primary tumors confined to gut, with no lymph node or distant metastases; $\mathrm{T}_{2-3} \mathrm{~N}_{1} \mathrm{M}_{0}$, patients with lymph node metastases but with no distant metastases; $\mathrm{T}_{3-4} \mathrm{~N}_{1-2} \mathrm{M}_{1}$, patients with distant metastases. Values are the means \pm SEM.

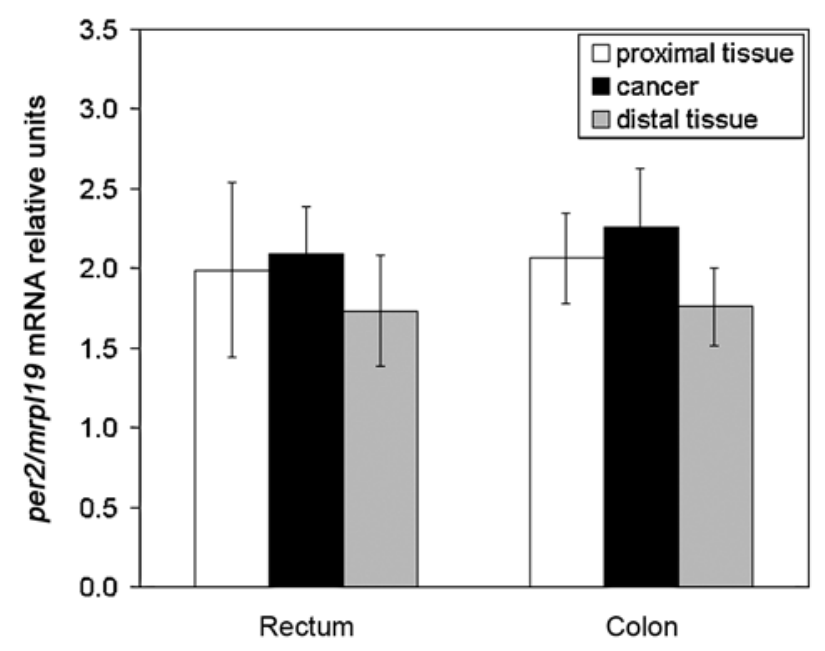

Figure 2. Expression of per2 in the tumor, proximal and distal areas of the resected rectum and colon. Values are the means \pm SEM.

was $>1$, implying lower per 2 gene expression in adjacent tissue than in tumor tissue. In patients with distant metastases, the above-mentioned ratio was $<1$, indicating lower per 2 gene expression in tumor tissue.

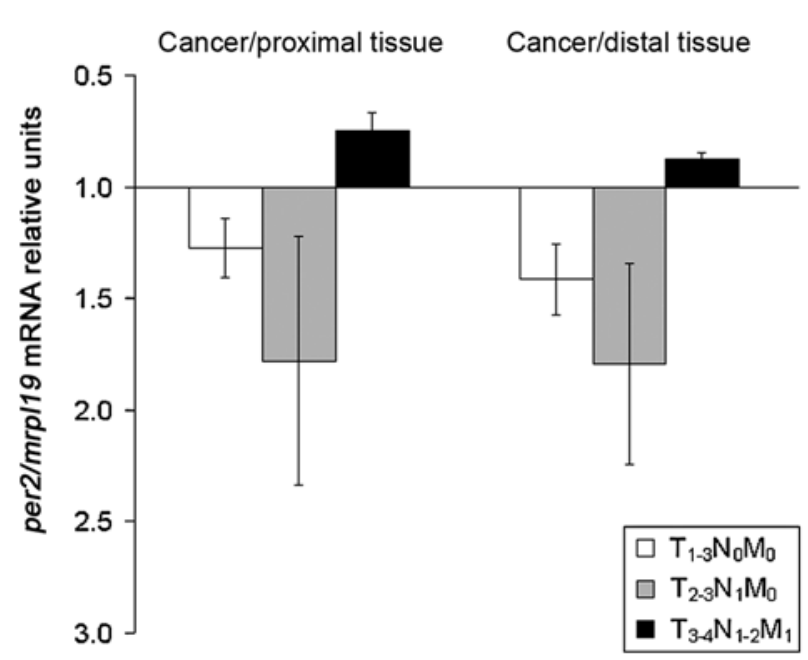

Figure 3. Ratio of per 2 mRNA expression in cancer and adjacent proximal or distal tissue. Values are the means \pm SEM. See Fig. 1 for tumor staging.

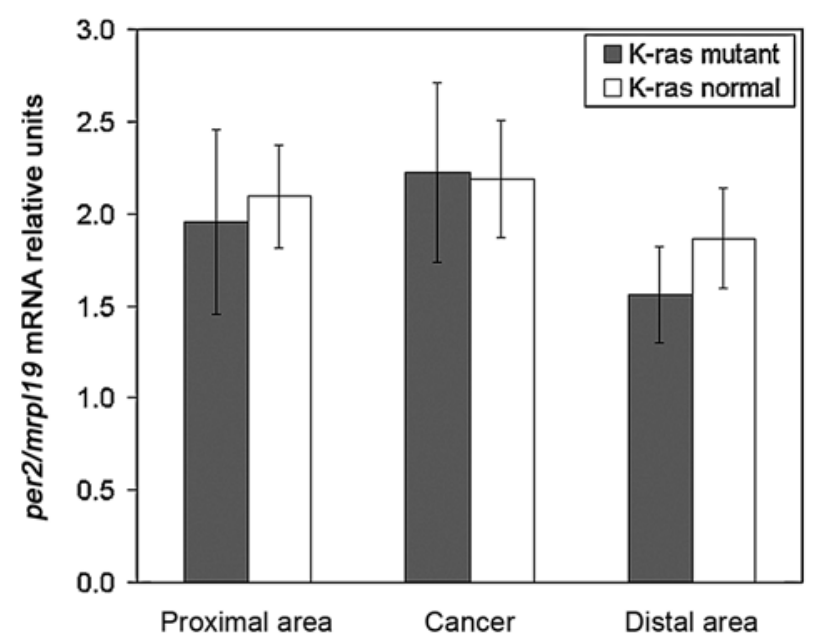

Figure 4. Expression of per 2 in the tumor, proximal and distal areas of the resected tissue in relation to the presence of K-ras mutation in codon $12(n=10)$ and K-ras non-mutated codon $12(\mathrm{n}=15)$. Values are the means \pm SEM.

K-ras mutations in codons 12 and 13 were detected in the cancer tissues (Fig. 4). The size of the PCR product was, as expected, 162 and 159 bp for codons 12 and 13, respectively. MvaI digestion of the wild-type $K$-ras codon 12 allele generated two bands of 133 and $29 \mathrm{bp}$, while mutant type remained intact (162 bp). Wild-type K-ras codon 13 PCR 
Table II. K-ras mutation frequency in cancer tissue depending on tumor stage.

\begin{tabular}{lrrrrrrr}
\hline & & \multicolumn{2}{c}{ K-ras } & & \multicolumn{2}{c}{ K-ras } \\
& & \multicolumn{2}{c}{ codon 12 $(\%)$} & & \multicolumn{2}{c}{ codon $13(\%)$} \\
& No. & Mutant & Normal & & Mutant & Normal \\
\hline $\mathrm{T}_{1-3} \mathrm{~N}_{0} \mathrm{M}_{0}$ & 16 & $6(37.5)$ & $10(62.5)$ & & 0 & $(0.0)$ & $16(100)$ \\
$\mathrm{T}_{2-3} \mathrm{~N}_{1} \mathrm{M}_{0}$ & 5 & $3(60.0)$ & $2(40.0)$ & & $1(20.0)$ & $4(80.0)$ \\
$\mathrm{T}_{3-4} \mathrm{~N}_{1-2} \mathrm{M}_{1}$ & 4 & $1(25.0)$ & $3(75.0)$ & & 0 & $(0.0)$ & $4(100)$ \\
Total & 25 & $10(40.0)$ & $15(60.0)$ & & 1 & $(4.0)$ & $24(96.0)$ \\
\hline
\end{tabular}

$\mathrm{T}_{1-3} \mathrm{~N}_{0} \mathrm{M}_{0}$, patients with primary tumors confined to the gut with no lymph node or distant metastases; $\mathrm{T}_{2-3} \mathrm{~N}_{1} \mathrm{M}_{0}$, patients with lymph node metastases but with no distant metastases; $\mathrm{T}_{3-4} \mathrm{~N}_{1-2} \mathrm{M}_{1}$, patients with distant metastases.

product was cleaved by $B s u$ RI into three fragments of 85 , 48 and $26 \mathrm{bp}$, while the mutant allele produced only two fragments of 85 and $74 \mathrm{bp}$. The average percentage of patients positive for codon 12 and 13 mutation was 40 and 4\%, respectively. Detailed analysis is presented in Table II. There was no significant difference in per 2 expression in patients positive for $K$-ras codon 12 mutation in cancer tissue and those without $K$-ras codon 12 mutation.

\section{Discussion}

Recent studies using per 2 gene deficient mice (10) have suggested that complex interactions between PER, several known regulators of the cell cycle and apoptosis may contribute to tumor development.

In the present study, we demonstrate for the first time the existence of a significant correlation between per 2 gene expression and tumor progress classified by the TNM staging system. A significant correlation between tumor stage and per 2 gene expression implicated the deregulation of per 2 gene expression in tumorigenesis, especially in patients with distant metastases. In these patients, per 2 gene expression was decreased in the tumor in comparison with the adjacent part of the resected gut.

Similar results were previously obtained when perl gene expression was measured in patients diagnosed with colon cancer (22). Several reports demonstrated deregulated expression of PER proteins in tumor tissue in comparison with the adjacent tissue of other kinds of cancer. Immunohistological analysis revealed deregulation of at least one of three PER proteins in 53 of 55 cases of breast cancer (25), and downregulated per 1 gene expression in non-small cell lung cancer (18) and endometrial carcinoma (26). Decreased levels of perl gene expression have also been observed when comparing breast cancer tumor-positive and -negative patients (18).

High variability in per gene expression is typical in most tumor cases, and may reflect different tumor staging and grading processes, or different treatment of patients. Our results generally agree with the data indicating the deregulation of per gene expression in tumor compared to adjacent tissue.
However, decreased expression of this gene was only observed in patients with distant metastases. It must be taken into consideration that colorectal tumors are exposed not only to systemic changes, but also to a variety of signals (molecules) coming from food and bacterial microflora, to which per 2 gene expression has previously been shown to be sensitive $(27,28)$.

Pathways mediating per 2 gene interference with tumor development may include interaction with the proto-oncogene $c-m y c$, which is involved in cell proliferation, differentiation and apoptosis. Overexpression of the $c-m y c$ gene has been detected in several types of human cancer, including colorectal carcinoma $(29,30)$. Expression of $c-m y c$ is under circadian control $(10,31)$, and rhythmic control of the expression of this gene has been found to be disrupted in per2 gene mutant mice (10). Another possibility is that PER2 interacts with kinase Wee1, which regulates the activity of the cyclindependent kinase 1/cyclin B1 complex and can be governed by the circadian clock via the E-box (10).

It is not clear, however, whether the rhythm of PER protein, its absolute levels or both are crucial to the effect of PER2 on tumor development and growth. Timing of drug administration, sampling time and gender may all influence the effectiveness and assessment of treatment (32). In vivo studies have proven that, in order to suppress tumor growth, the capacity of the cyclin-dependent kinase inhibitor Seliciclib must be phase dependent. Seliciclib was most efficient when administered at a time corresponding to the time at which treatment established the proper phase relationship of the oscillating clock genes (13). Several experiments employing cell lines have demonstrated that increased per gene expression leads to the suppression of growth of the transformed cells (17-19), and per2 has been suggested as a novel therapeutic strategy for the treatment of malignant tumors $(20,33)$.

Colorectal cancer development is frequently related to the mutation of another proto-oncogen, $K$-ras (34). K-ras is a member of a highly conserved family of GTPases, including $\mathrm{H}$-ras and $\mathrm{N}$-ras, which encodes the $21-\mathrm{kD}$ protein. The rasproteins are molecular switches that bind to GTP in their active state. Normally, this binding process is strictly controlled and depends on interactions between receptor tyrosine kinases and a network of intracellular proteins. Oncogenic forms of ras-proteins are permanently activated by bound GTP. This is caused by mutations in the nucleotide binding site of these proteins and results in the prevention of the hydrolysis of GTP into GDP $(35,36)$. Missense mutations in codons 12 and 13 of exon 1 of the $K$-ras gene are found in $30-60 \%$ of colorectal tumors (37-39). The mutation frequency of $\mathrm{K}$-ras in codon 12 in our cohort of patients was $40 \%$, which corresponds with the published data (37-39). We did not find any significant correlation between mutations in exon 1 of $K$-ras and expression of the per 2 gene in the colorectal tumors analyzed.

In conclusion, our data suggest that tumor staging correlates more closely with per 2 gene expression than tumor location does in colorectal carcinoma. This finding may suggest a specific function for the per 2 gene in the process of tumorigenesis. We suggest that a proper relationship between the rhythmic expression of clock components and their absolute values may play a role in cancer development, and that their deficit or absence may negatively influence the progress of the disease. 


\section{Acknowledgements}

This study was supported by grants APVV-0214-07, VEGA $1 / 4328 / 07$ and $1 / 4343 / 07$. We thank Dr A. Kiss for critically reading the manuscript.

\section{References}

1. Schernhammer ES, Laden F, Speizer FE, Willett WC, Hunter DJ, Kawachi I, Fuchs CS and Colditz GA: Night-shift work and risk of colorectal cancer in the nurses' health study. J Natl Cancer Inst 95: 825-828, 2003.

2. Davis S, Mirick DK and Stevens RG: Night shift work, light at night and risk of breast cancer. J Natl Cancer Inst 93: 1557-1562, 2001.

3. Hansen J: Increased breast cancer risk among women who work predominantly at night. Epidemiology 12: 74-77, 2001.

4. Schernhammer ES, Laden F, Speizer FE, Willett WC, Hunter DJ, Kawachi I and Colditz GA: Rotating night shifts and risk of breast cancer in women participating in the nurses' health study. J Natl Cancer Inst 93: 1563-1568, 2001.

5. Ko CH and Takahashi JS: Molecular components of the mammalian circadian clock. Hum Mol Genet 15: R271-R277, 2006.

6. Damiola F, Le Minh N, Preitner N, Kornmann B, Fleury-Olela F and Schibler U: Restricted feeding uncouples circadian oscillators in peripheral tissues from the central pacemaker in the suprachiasmatic nucleus. Genes Dev 14: 2950-2961, 2000.

7. Hara R, Wan K, Wakamatsu H, Aida R, Moriya T, Akiyama M and Shibata S: Restricted feeding entrains liver clock without participation of the suprachiasmatic nucleus. Genes Cells 6: 269-278, 2001.

8. Stokkan KA, Yamazaki S, Tei H, Sakaki Y and Menaker M: Entrainment of the circadian clock in the liver by feeding. Science 291: 490-493, 2001.

9. Okamura H, Yamaguchi S and Yagita K: Molecular machinery of the circadian clock in mammals. Cell Tissue Res 309: 47-56, 2002.

10. Fu L, Pelicano H, Liu J, Huang P and Lee C: The circadian gene Period2 plays an important role in tumor suppression and DNA damage response in vivo. Cell 111: 41-50, 2002.

11. Matsuo T, Yamaguchi S, Mitsui S, Emi A, Shimoda F and Okamura H: Control mechanism of the circadian clock for timing of cell division in vivo. Science 302: 255-259, 2003.

12. Miller BH, McDearmon EL, Panda S, Hayes KR, Zhang J, Andrews JL, Antoch MP, Walker JR, Esser KA, Hogenesch JB and Takahashi JS: Circadian and CLOCK-controlled regulation of the mouse transcriptome and cell proliferation. Proc Natl Acad Sci USA 104: 3342-3347, 2007.

13. Iurisci I, Filipski E, Reinhardt J, Bach S, Gianella-Borradori A, Iacobelli S, Meijer L and Lévi F: Improved tumor control through circadian clock induction by Seliciclib, a cyclindependent kinase inhibitor. Cancer Res 66: 10720-10728, 2006.

14. Filipski E, Delaunay F, King VM, Wu MW, Claustrat B, Gréchez-Cassiau A, Guettier C. Hastings MH and Francis L: Effects of chronic jet lag on malignant growth in mice. Cancer Res 64: 7879-7885, 2004.

15. Filipski E, Innominato PF, Wu M, Li XM, Iacobelli S, Xian LJ and Lévi F: Effects of light and food schedules on liver and tumor molecular clocks in mice. J Natl Cancer Inst 97: 507-517, 2005.

16. Granda TG, Liu XH, Smaaland R, Cermakian N, Filipski E, Sassone-Corsi P and Lévi F: Circadian regulation of cell cycle and apoptosis proteins in mouse bone marrow and tumor. FASEB J 19: 304-306, 2005.

17. Gery S, Gombart AF, Yi WS, Koeffler C, Hofmann WK and Koeffler HP: Transcription profiling of C/EBP targets identifies Per2 as a gene implicated in myeloid leukemia. Blood 106: 2827-2836, 2005

18. Gery S, Komatsu N, Baldjyan L, Yu A, Koo D and Koeffler HP: The circadian gene per1 plays an important role in cell growth and DNA damage control in human cancer cells. Mol Cell 22: 375-382, 2006.

19. Hua H, Wang Y, Wan C, Liu Y, Zhu B, Yang C, Wang X, Wang Z, Cornelissen-Guillaume G and Halberg F: Circadian gene mPer2 overexpression induces cancer cell apoptosis. Cancer Sci 97: 589-596, 2006.

20. Hua H, Wang Y, Wan C, Liu Y, Zhu B, Wang X, Wang Z and Ding JM: Inhibition of tumorigenesis by intratumoral delivery of the circadian gene mPer2 in C57BL/6 mice. Cancer Gene Ther 14: 815-818, 2007.
21. Pardini L, Kaeffer B, Trubuil A, Bourreille A and Galmiche JP: Human intestinal circadian clock: expression of clock genes in colonocytes lining the crypt. Chronobiol Int 22: 951-961, 2005.

22. Krugluger W, Brandstaetter A, Kállay E, Schueller J, Krexner E, Kriwanek S, Bonner E and Cross HS: Regulation of genes of the circadian clock in human colon cancer: reduced period-1 and dihydropyrimidine dehydrogenase transcription correlates in high-grade tumors. Cancer Res 67: 7917-7922, 2007.

23. Szabo A, Perou CM, Karaca M, Perreard L, Quackenbush JF and Bernard PS: Statistical modeling for selecting housekeeper genes. Genome Biol 5: R59, 2004.

24. Hatzaki A, Razi E, Anagnostopoulou K, Iliadis K, Kodaxis A, Papaioannou D, Labropoulos S, Vasilaki M, Kosmidis P, Saetta A, Mihalatos M and Nasioulas G: A modified mutagenic PCR-RFLP method for K-ras codon 12 and 13 mutations detection in NSCLC patients. Mol Cell Probes 15: 243-247, 2001.

25. Chen ST, Choo KB, Hou MF, Yeh KT, Kuo SJ and Chang JG: Deregulated expression of the PER1, PER2 and PER3 genes in breast cancers. Carcinogenesis 26: 1241-1246, 2005.

26. Yeh KT, Yang MY, Liu TC, Chen JC, Chan WL, Lin SF and Chang JG: Abnormal expression of period 1 (PER1) in endometrial carcinoma. J Pathol 206: 111-120, 2005.

27. Iwanaga H, Yano M, Miki H, Okada K, Azama T, Takiguchi S, Fujiwara Y, Yasuda T, Nakayama M, Kobayashi M, Oishi K, Ishida N, Nagai K and Monden M: Per2 gene expressions in the suprachiasmatic nucleus and liver differentially respond to nutrition factors in rats. JPEN J Parenter Enteral Nutr 29: 157-161, 2005.

28. Hirota T, Okano T, Kokame K, Shirotani-Ikejima H, Miyata T and Fukada Y: Glucose down-regulates Per1 and Per2 mRNA levels and induces circadian gene expression in cultured Rat-1 fibroblasts. J Biol Chem 277: 44244-44251, 2002.

29. Greco C, Alvino S, Buglioni S, Assisi D, Lapenta R, Grassi A, Stigliano V, Mottolese M and Casale V: Activation of c-MYC and c-MYB proto-oncogenes is associated with decreased apoptosis in tumor colon progression. Anticancer Res 21: 3185-3192, 2001.

30. Kakisako K, Miyahara M, Uchino S, Adachi Y and Kitano S: Prognostic significance of c-myc mRNA expression assessed by semi-quantitative RT-PCR in patients with colorectal cancer. Oncol Rep 5: 441-445, 1998.

31. Nakamura KD, Duffy PH, Lu MH, Turturro A and Hart RW: The effect of dietary restriction on myc protooncogene expression in mice: a preliminary study. Mech Ageing Dev 48: 199-205, 1989.

32. Giacchetti S, Bjarnason G, Garufi C, Genet D, Iacobelli S, Tampellini M, Smaaland R, Focan C, Coudert B, Humblet Y, Canon JL, Adenis A, Lo Re G, Carvalho C, Schueller J, Anciaux N, Lentz MA, Baron B, Gorlia T, Lévi F and the European Organisation for Research and Treatment of Cancer Chronotherapy Group: Phase III trial comparing 4-day chronomodulated therapy versus 2-day conventional delivery of fluorouracil, leucovorin and oxaliplatin as first-line chemotherapy of metastatic colorectal cancer: the European Organisation for Research and Treatment of Cancer Chronotherapy Group. J Clin Oncol 24: 3562-3569, 2006.

33. Chen-Goodspeed $\mathrm{M}$ and Lee CC: Tumor suppression and circadian function. J Biol Rhythms 22: 291-298, 2007.

34. Vogelstein B and Kinzler KW: Cancer genes and the pathways they control. Nat Med 10: 789-799, 2004.

35. Rodenhuis S: ras and human tumors. Semin Cancer Biol 3: 241-247, 1992.

36. Huncharek M, Muscat J and Geschwind JF: K-ras oncogene mutation as a prognostic marker in non-small cell lung cancer: a combined analysis of 881 cases. Carcinogenesis 20: 1507-1510, 1999.

37. Breivik J, Meling GI, Spurkland A, Rognum TO and Gaudernack G: K-ras mutation in colorectal cancer: relations to patient age, sex and tumour location. Br J Cancer 69: 367-371, 1994.

38. Samowitz WS, Curtin K, Schaffer D, Robertson M, Leppert M and Slattery ML: Relationship of Ki-ras mutations in colon cancers to tumor location, stage and survival: a population-based study. Cancer Epidemiol Biomarkers Prev 9: 1193-1197, 2000.

39. Lüchtenborg M, Weijenberg MP, Wark PA, Saritas AM, Roemen GM, van Muijen GN, De Bruïne AP, van den Brandt PA and De Goeij AF: Mutations in APC, CTNNB1 and K-ras genes and expression of hMLH1 in sporadic colorectal carcinomas from the Netherlands Cohort Study. BMC Cancer 5: 160-171, 2005. 